\title{
EDITORIAL
}

\section{PNDT and other issues}

\section{Bhavin Jankharia}

Editor-in-Chief, Indian Journal of Radiology and Imaging, Bhaveshwar Vihar, 383 Sardar V P Road, Prarthana Samaj, Mumbai - 400 004, India. E-mail: editor@ijri.org

Half of this issue is devoted to various aspects of the PC-PDNT Act. The Act itself is covered in brief, along with a short article on how to fill up the " $F$ " form, articles from social workers and others working in this field, articles on what happens when we do not adhere to the law, and some view points from other colleagues.

This issue is incomplete, because the PNDT Act keeps changing every week. In fact this issue was delayed because we were trying to stay abreast of these frequent changes. We expect follow-up articles in the forthcoming issues.

I would like to thank Dr. Jignesh Thakker and Dr. Sanjeev Mani for their tireless efforts in bringing out this special issue.

The rest of the issue deals with interventional articles on radiofrequency ablation of varicose veins and the use of highintensity focused ultrasound for focal adenomyosis along with a short technical note on MRI lymphography.

\begin{tabular}{|l|l|}
\hline \multicolumn{2}{|c|}{ Access this article online } \\
\hline Quick Response Code: & \\
\hline & Website: \\
\hline
\end{tabular}

